\title{
Effects of immunocastration performed at two live weights on the growth physiology, temperament and testicular development of feral beef bulls
}

\author{
Agustí Noya (D) | Guillermo Ripoll (iD | Isabel Casasús (iD | Albina Sanz (D)
}

Centro de Investigación y Tecnología Agroalimentaria (CITA) de Aragón, Instituto Agroalimentario de Aragón - IA2 (CITAUniversidad de Zaragoza), Zaragoza, Spain

Correspondence

Albina Sanz, Centro de Investigación y Tecnología Agroalimentaria (CITA) de Aragón. Instituto Agroalimentario de Aragón - IA2 (CITA-Universidad de Zaragoza). Avenida Montañana 930, 50059 Zaragoza, Spain. Email: asanz@aragon.es

Funding information

Teruel Investment Funds, Grant/Award Number: FITE 451A and FITE 551A; Spanish Ministry of Science, Innovation and Universities, Grant/Award Number: INIA RTA 2013-00059-C02; Government of Aragón, Grant/Award Number: A14_17R

\begin{abstract}
The aim of this study was to examine the effect of administering an anti-gonadotropin-releasing hormone vaccine (Improvac ${ }^{\circledR}$, developed for pigs) on the performance, temperament, testicular development, and hormone and metabolite profiles of feral bulls (Bos taurus) vaccinated at two different live weights (LW). In all, 16 Serrana de Teruel animals were involved in this $2 \times 2$ factorial design using the factors LW (LIGHT vs. HEAVY) and vaccine treatment (control, $C$ vs. vaccinated, VA). All animals received the same diet (ad libitum concentrate plus straw) over a 164-day fattening period. Temperament was assessed using chute and flight speed tests. Testicular diameter and subcutaneous fat thickness were recorded. Testosterone, IGF-1, urea, NEFA, and creatinine profiles were analyzed. Bull weight gain was reduced in VA compared to $C$ animals, regardless of the initial LW. The vaccine did not affect the temperament tests, subcutaneous fat thickness or NEFA and creatinine concentrations and had minor effects on linear body measures. The vaccine inhibited testicular growth, reduced plasma testosterone to residual levels, and increased urea concentrations. LIGHT-C animals exhibited increased mean plasma IGF-1 concentrations compared to LIGHT-VA animals. In conclusion, vaccination reduced bull growth and sexual development irrespective of LW at immunization.

KEYWORDS

anti-gonadotropin-releasing hormone (anti-GnRH) vaccine, behavior, IGF-1, testosterone
\end{abstract}

\section{1 | INTRODUCTION}

Physical castration, either surgically using rubber bands or using an emasculator, is a common technique performed to remove male aggressive and sexual behavior (Stafford \& Mellor, 2005), to facilitate management (Pang, Earley, Gath, \& Crowe, 2008) or to improve the physicochemical characteristics of the meat, increasing marbling and tenderness (Creutzinger et al., 2017; Ripoll, Albertí, Álvarez-Rodríguez, Blasco, \& Sanz, 2016). However, castration is controversial with respect to animal welfare because it imparts pain, inflammatory reactions, and post-castration discomfort (Coetzee, 2011), which can impair animal productive performance.
Immunocastration is a non-invasive technique based on administration of an anti-gonadotropin-releasing hormone (anti-GnRH) vaccine that stimulates the immune system to produce antibodies against endogenous gonadotropin-releasing hormone (GnRH). The neutralization of $\mathrm{GnRH}$ halts the production of luteinizing hormone (LH), follicle-stimulating hormone (FSH), and, ultimately, testosterone (Brunius et al., 2011). Improvac ${ }^{\circledR}$ and Bopriva ${ }^{\circledR}$ are the most commonly used anti-GnRH commercial vaccines for swine and cattle, respectively. Whereas the former is widely used in the European Union to control boar taint in male pigs, the latter is not yet authorized for use in cattle. The mechanism of action for both vaccines is the same, with adjuvant type being the sole difference between 
them. Efficacy of both vaccines has been previously demonstrated in swine (Wicks, Crouch, \& Pearl, 2013).

Serrana de Teruel (Bos taurus) is a Spanish feral beef breed adapted to harsh environmental conditions that is managed with minimal human contact. These minimal interventions include, for example, that calves born throughout a long and irregular calving season (Vijil et al., 2009) are weaned at a single date, resulting in age and weight at weaning being highly variable. Furthermore, extensive management of feral cattle exacerbate their temperamental behavior (Fina, Casellas, Manteca, \& Piedrafita, 2006). To ease handling, reduce sexual and aggressive behavior and improve their poor conformed carcasses during the finishing phase, Serrana de Teruel males are sometimes castrated (Sanz et al., 2013). ÁlvarezRodríguez, Albertí, Ripoll, Blasco, and Sanz (2017) described that physical castration causes pain and distress to the animals, triggering weight loss primarily in the month following castration and at the end of the fattening period. Therefore, other alternative methods should be explored.

The aim of this study was to evaluate the effects of an anti-GnRH vaccine $\left(I m p r o v a c{ }^{\circledR}\right)$ as an alternative to physical castration with respect to growth, temperament, testicular development, and plasma hormones and metabolites in a feral beef breed (Serrana de Teruel) vaccinated at two different live weights (LW).

\section{2 | MATERIALS AND METHODS}

This study was performed at the Centro de Investigación y Tecnología Agroalimentaria (CITA) of Aragón, Zaragoza, Spain. The Animal Ethics Committee of CITA approved all procedures, and care and use of animals were in accordance with current normative regulations (R.D.53/2013), which meet the Union Directive 2010/63 on the protection of animals used for experimental and other scientific purposes.

\subsection{Animal management}

In all, 16 newly weaned Serrana de Teruel males provided by the Serrana de Teruel Breeders Association (ASERNA) were used in this study, following a $2 \times 2$ experimental design. After 15 days of preexperimental adaptation to feedlot facilities and diet, calves were divided into two groups depending on their initial LW (LIGHT vs. HEAVY). Half of the animals in each group were randomly selected to comprise the control group (C), while the other half was vaccinated (VA). According to the commercial Bopriva ${ }^{\circledR}$ planning (which states that the priming dose and the booster one must be applied at least 21 days apart, and the following doses must be applied within 90 days), the VA group received three subcutaneous 2- $\mathrm{mL}$ doses of anti-GnRH vaccine (Improvac ${ }^{\circledR}$; Zoetis, Parsippany, NJ, USA) in the right shoulder blade on day 1 (priming dose), day 21 (booster), and day 104 of the experimental period. This resulted in four total groups with respect to the initial LW and vaccine treatment (mean \pm standard deviation): LIGHT-C (164 $\pm 21.5 \mathrm{~kg} \mathrm{LW}, 8.0 \pm 1.43$ months of age), LIGHT-VA (182 \pm 37.7 kg LW, $7.8 \pm 0.93$ months), HEAVY-C (341 $\pm 33.8 \mathrm{~kg} \mathrm{LW}, 11.1 \pm 2.36$ months), and HEAVY-VA (307 \pm 37.4 kg LW, $10.6 \pm 2.14$ months). Each group was loose housed in a pen, where animals received ad libitum a commercial concentrate (Table 1) and barley straw during a fattening period that lasted $164 \pm 8.8$ days for all groups until the day prior to slaughter.

\subsection{Measurements and sampling}

During the fattening period, animals were weighed every 2 weeks, and average daily gain (ADG) was calculated by linear regression for the duration of the experiment, and for the different phases between the three sequential vaccine doses and from the last dose to the end of the study. Concentrate and barley straw intake (offer minus refusals) were recorded daily per group (mean values) to calculate the feed conversion ratio (mean values).

Linear body measurements were determined as described by Ripoll et al. (2016) on day 1, 104 and 149 during the experimental period. Variables included height at withers and rump, chest girth, rump width and length, and body length.

Chute and flight speed tests were performed to assess temperament on day $1,28,104$, and 146 . In the chute test, animals remained

TABLE 1 Ingredients and chemical composition of the concentrate used in the experiment (as fed basis)

\begin{tabular}{|ll|}
\hline Ingredients, \% & \\
\hline Corn & 47.20 \\
\hline Corn gluten feed & 15.00 \\
\hline Barley & 15.00 \\
\hline Soya flour & 6.11 \\
\hline Sunflower pulp & 5.96 \\
\hline Carob flour & 4.00 \\
\hline Palm oil & 3.50 \\
\hline Calcium carbonate & 1.28 \\
\hline Urea & 0.60 \\
\hline Calcium bicarbonate & 0.50 \\
\hline Sodium chloride & 0.30 \\
\hline Magnesium oxide & 0.30 \\
\hline Vitamin-mineral corrector & 0.20 \\
\hline Fungi and yeast controller & 0.05 \\
\hline Chemical composition & \\
\hline DM, g/kg FM & $898.8 \pm 0.81$ \\
\hline CP, g/kg DM & $146.3 \pm 0.56$ \\
\hline NDF, g/kg DM & $240.9 \pm 2.33$ \\
\hline ADF, g/kg DM & $71.5 \pm 0.72$ \\
\hline ADL, g/kg DM & $14.5 \pm 0.30$ \\
\hline Ash, g/kg DM & $66.2 \pm 1.34$ \\
\hline ME, MJ/kg DM & $15.2 \pm 0.17$ \\
\hline
\end{tabular}

Abbreviations: ADF, acid detergent fiber; ADL, lignin-acid detergent fiber; $C P$, crude protein; DM, dry matter; FM, fresh matter; $M E$, metabolizable energy; NDF, neutral detergent fiber. 
in a single animal weighing scale for $30 \mathrm{~s}$ and the behavior of the animal in the scale was scored on a 4-point scale (1-quiet to 4-violent struggling) (adapted from Grandin (1993)). In the flight speed test, when animals left the scale, time to go ahead a distance of $5 \mathrm{~m}$ was recorded using a stopwatch to calculate flight speed. Animals with high flight speed scores are associated with more temperamental behavior, whereas docile animals vacate a weigh scale at a slower pace than others (adapted from Burrow, Seifert, and Corbet (1988)).

To evaluate growth of the testes, ultrasound examination (Aloka SSD-500; Aloka) was performed of each testicle using a 7.5 MHz linear probe to measure testicular diameter, thickness of the mediastinum, and echogenicity of the testicular parenchyma on day 1, 21, 61,104 , and 164 of the fattening period. Ultrasound settings (focus, gains, brightness, and contrast) were standardized for all examinations. The probe was placed at the back of the scrotum in the sagittal plane (parallel to the major axis of the testicle) to measure mediastinum thicknesses and in a horizontal plane to measure testicular diameter. Echotexture was also analyzed from the ultrasound images. For this purpose, maximum possible and representative areas in the posterior testicular parenchyma were selected and processed using ImageJ v1.48 (National Institutes of Health, Bethesda). Pixel intensity was measured using a 255-point scale (0-anechoic to 255hyperechoic) (Pinho et al., 2012), and results were expressed as a percentage. On the same days, testicular evaluations occurred, subcutaneous fat thickness was measured using ultrasonography with the same probe on top of the 13th thoracic vertebra and at the 3rd sacral vertebra over the gluteus medius and biceps femoris muscles (P8 point) (Robinson, McDonald, Hammond, \& Turner, 1992).

Blood samples were collected monthly by tail vessel puncture between the 6th and 7th coccygeal vertebrae in $10 \mathrm{ml}$ Vacutainer tubes (Becton Dickinson). After blood collection, samples were centrifuged at $1,500 \times \mathrm{g}$ for $20 \mathrm{~min}$ at $4^{\circ} \mathrm{C}$, and plasma was stored at $-20^{\circ} \mathrm{C}$ for further analyses.

\section{3 | Assays}

According to the manufacturers' instructions, EDTA or heparin plasma samples were used to determinate blood concentrations of testosterone (ng/dL), insulin-like growth factor 1 (IGF-1, ng/mL), urea (mmol/L), non-esterified fatty acids (NEFA, mmol/L), and creatinine $(\mathrm{mmol} / \mathrm{L})$. Testosterone concentrations were determined using a commercial kit according to the manufacturer's instructions (Testo-EASIA kit; DIAsource Immunoassays S.A., Louvain-La-Neuve, Belgium); the intra- and inter-assay coefficients of variation (CVs) were $4.85 \%$ and $7.15 \%$, respectively. Concentrations of IGF-1 were determined using an amplified chemiluminescent immunometric assay (Immulite; Siemens Medical Solutions Diagnostics Limited) with intra- and inter-assay CVs of $3.1 \%$ and $12.0 \%$, respectively. For urea determination, an automatic analyzer GernonStar (RAL/Transasia) was used, and intra- and inter-assay CVs were $4.4 \%$ and $5.8 \%$, respectively. NEFA were analyzed using a commercial kit (Randox Laboratories, Barcelona) with intra- and inter-assay CVs of $5.1 \%$ and $7.4 \%$, respectively. Creatinine concentrations were determined using an automatic analyzer GernonStar (RAL/Transasia), and intraand inter-assay CVs were $4.4 \%$ and $5.8 \%$, respectively.

\section{4 | Statistical analysis}

All statistics were calculated using SAS statistical package v 9.4 (SAS Institute Inc.). The normal distribution of data was assessed using the Shapiro-Wilk test. Normality could not be confirmed for testosterone; therefore, its concentrations were expressed as a decimal logarithm for further analyses.

Initial and final LW, ADG throughout the experimental period, and age of slaughter were analyzed using a generalized linear model (GLM procedure) with the initial LW (LIGHT vs. HEAVY) and vaccination (C vs. VA) as fixed effects. Chute score, flight speed, linear body and testicular measurement, subcutaneous fat thickness and blood metabolite, and hormone concentration were analyzed using the MIXED procedures for repeated measures based on KenwardRoger's adjusted degrees of freedom solution. Fixed factors were $\mathrm{LW}$ and vaccination as between-subject effects, time as the withinsubject effect, and animal as the random effect (experimental unit). The Akaike information criterion closest to zero was used to choose the matrix of the error structure. The least square (LS) means of treatments were estimated per fixed effect, and pair-wise comparisons of means were obtained by the probability of difference (PDIFF) option of the LS means procedure. The relationship among testicular diameter and metabolite and hormone concentrations were determined using Pearson's correlation coefficients. The level of significance for all tests was $p<.05$. The results are presented as LS means \pm standard error. Feed intake and feed conversion ratio were not statistically tested because intake was registered on a group basis; therefore, only group means are presented.

\section{3 | RESULTS}

None of the vaccinated animals experienced any adverse reactions due to subcutaneous administration of the anti-GnRH vaccine.

\section{1 | Animal performance}

Bull LW and weight gain are shown in Table 2. Due to the experimental design, the initial LW was greater in HEAVY than in LIGHT bulls, which remained significantly different through the end of the study $(p<.001)$. Initial LW did not differ between vaccine treatments, but at the end, $C$ animals were heavier than VA bulls $(p<.05)$. Neither the initial LW nor vaccine treatment influenced ADG from the priming dose (day 1) to the booster (day 21). However, from the booster to third dose (day 104), from the third dose to the day before slaughter (day 164), and throughout the fattening period, the VA group exhibited lower ADG than their $C$ counterparts $(p<.01)$. Straw intake throughout the experiment was $0.9 \pm 0.29 \mathrm{~kg} \mathrm{DM} /$ day, and mean values of concentrate intake are shown in Figure 1. HEAVY and $C$ animals had higher concentrate intake than LIGHT and VA animals, 


\begin{tabular}{|c|c|c|c|c|c|c|c|c|}
\hline & \multicolumn{2}{|l|}{ LW } & \multicolumn{2}{|l|}{$\mathrm{T}$} & \multirow[b]{2}{*}{ S.E. } & \multicolumn{3}{|c|}{ Significance } \\
\hline & Light & Heavy & $\mathrm{C}$ & VA & & LW & $\mathrm{T}$ & $\mathrm{LW} \times \mathrm{T}$ \\
\hline $\begin{array}{l}\text { Initial weight (day } \\
\text { 0), kg }\end{array}$ & $179^{b}$ & $330^{a}$ & 260 & 249 & 21.2 & $* * *$ & ns & ns \\
\hline $\begin{array}{l}\text { Final weight (day } \\
\text { 164), kg }\end{array}$ & $409^{b}$ & $555^{a}$ & $5128^{x}$ & $4513^{y}$ & 15.25 & $* * *$ & * & ns \\
\hline $\begin{array}{l}\mathrm{ADG}_{\text {phase } 1}, \mathrm{~kg} / \\
\text { day }\end{array}$ & 1.08 & 1.25 & 1.18 & 1.15 & 0.114 & ns & ns & ns \\
\hline $\begin{array}{l}\text { ADG phase 2, kg/ } \\
\text { day }\end{array}$ & 1.67 & 1.59 & $1.82^{\mathrm{x}}$ & $1.43^{y}$ & 0.085 & ns & $* *$ & ns \\
\hline $\begin{array}{l}\mathrm{ADG}_{\text {phase } 3}, \mathrm{~kg} / \\
\text { day }\end{array}$ & 1.15 & 1.07 & $1.36^{x}$ & $0.86^{y}$ & 0.094 & ns & $* *$ & ns \\
\hline $\mathrm{ADG}_{\text {total }}, \mathrm{kg} / \mathrm{day}$ & 1.51 & 1.47 & $1.64^{x}$ & $1.33^{y}$ & 0.072 & ns & $* *$ & ns \\
\hline
\end{tabular}

TAB LE 2 Bull live weights and performances during the experimental period according to the initial LW and vaccine treatment

Abbreviations: $A D G_{\text {phase } 1}$, average daily gain from 1st vaccine dose (day 1 ) to 2 nd vaccine dose (booster, day 21); ADG phase 2, average daily gain from 2 nd vaccine dose (booster, day 21) to 3rd vaccine dose (day 104); ADG phase 3 , average daily gain from 3rd vaccine dose (day 104) to the day before slaughter (day 164); ADG total, average daily gain along the experimental period; C, control group; LW, initial live weight; S.E., standard error; T, vaccine treatment; VA, vaccinated group.

$\mathrm{ns} ; p>.05$

a,b Means within a row with different superscripts differing significantly between initial LW

$(p<.05)$.

${ }^{\mathrm{x}, \mathrm{y}}$ Means within a row with different superscripts differing significantly between vaccine treatment

$(p<.05)$.

${ }^{*} p<.05$

${ }^{* *} p<.01$

${ }^{* * *} p<.001$

respectively. However, as the ADG was numerically higher in LIGHT and significantly higher in $\mathrm{C}$ animals, feed conversion was lower in the LIGHT group (4.4 \pm 0.01 vs. $5.8 \pm 0.01$ concentrate $\mathrm{kg}$ DM/LW kg for LIGHT and HEAVY, respectively) and in those that had not been vaccinated ( $4.8 \pm 0.01$ vs. $5.5 \pm 0.01$ concentrate $\mathrm{kg}$ DM/LW kg for $C$ and VA, respectively).

Linear body measures throughout the study are shown in Table 3. All measures were influenced by the initial LW category and time, or their interaction $(p<.05)$. Furthermore, height at withers, chest girth, and rump length measurements were also affected by the interaction between the initial LW category and vaccine treatment $(p<.05)$ and body length by the interaction between vaccine treatment and time $(p<.05)$. In general, body linear measures increased throughout the study, being higher in HEAVY than in LIGHT animals; however, vaccination reduced the differences between HEAVY-VA and LIGHT animals.

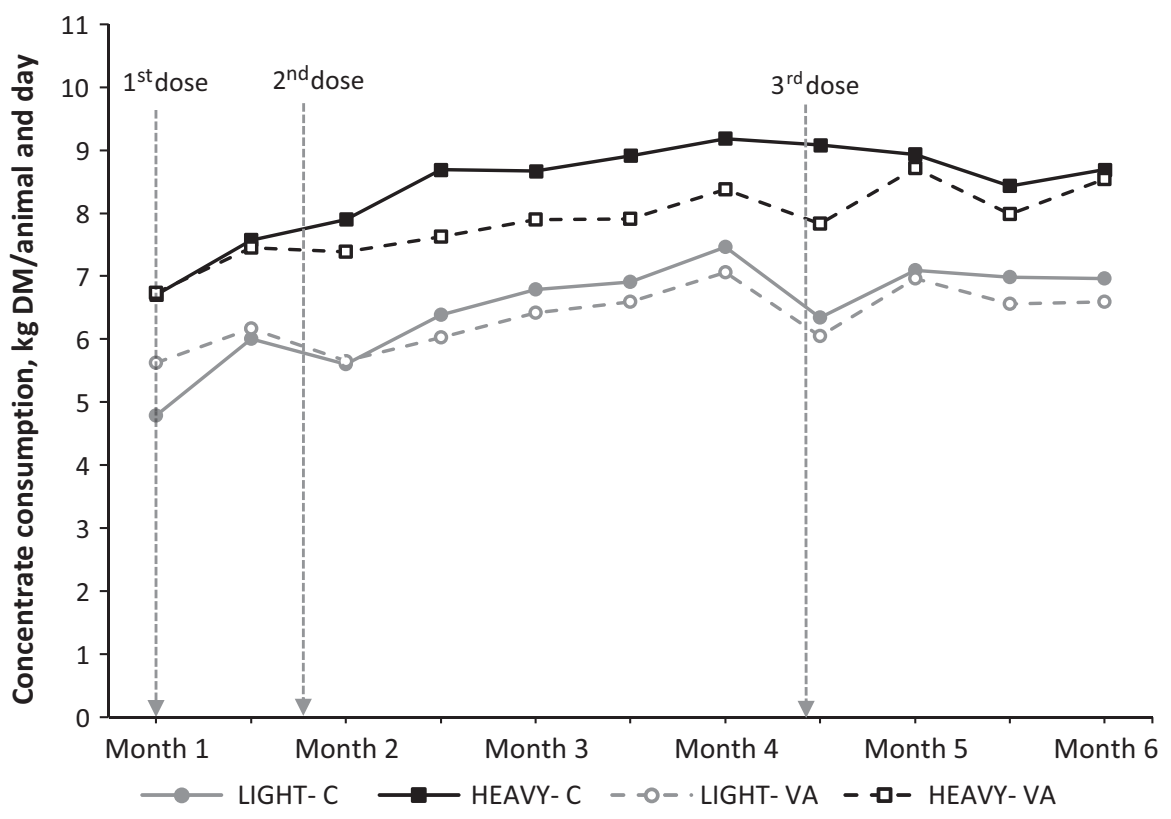

FIGURE 1 Mean values of concentrate intake during the experimental period according to the initial LW and vaccine treatment 
TAB LE 3 Linear body measures in bulls during the experimental period according to the initial LW and vaccine treatment

\begin{tabular}{|c|c|c|c|c|c|c|c|c|}
\hline & \multirow[b]{2}{*}{ LIGHT-C } & \multirow[b]{2}{*}{ LIGHT-VA } & \multirow[b]{2}{*}{ HEAVY-C } & \multirow[b]{2}{*}{ HEAVY-VA } & \multirow[b]{2}{*}{ S.E. } & \multicolumn{3}{|c|}{ Significance } \\
\hline & & & & & & LW & $\mathrm{T}$ & $\mathrm{LW} \times \mathrm{T}$ \\
\hline \multicolumn{9}{|c|}{ Height at withers, $\mathrm{cm}$} \\
\hline day 1 & $101.3^{c}$ & $103.3^{b c}$ & $115.8^{a}$ & $110.5^{\mathrm{ab}}$ & 1.45 & \multirow[t]{3}{*}{$* * *$} & \multirow[t]{3}{*}{ ns } & \multirow[t]{3}{*}{ * } \\
\hline day 104 & $115.5^{b}$ & $116.5^{\mathrm{ab}}$ & $123.3^{a}$ & $120.8^{a b}$ & 1.45 & & & \\
\hline day 149 & $116.0^{b}$ & $117.0^{b}$ & $125.3^{a}$ & $121.3^{a b}$ & 1.45 & & & \\
\hline \multicolumn{9}{|c|}{ Height at rump, cm } \\
\hline day 1 & $106.8^{b}$ & $107.5^{b}$ & $122.3^{a}$ & $117.8^{a}$ & 1.56 & \multirow[t]{3}{*}{$* * *$} & \multirow[t]{3}{*}{ ns } & \multirow[t]{3}{*}{ ns } \\
\hline day 104 & $120.8^{b}$ & $121.5^{b}$ & $133.0^{a}$ & $127.8^{a b}$ & 1.56 & & & \\
\hline day 149 & $124.5^{b}$ & $124.3^{b}$ & $133.5^{a}$ & $130.3^{a b}$ & 1.56 & & & \\
\hline \multicolumn{9}{|c|}{ Chest girth, $\mathrm{cm}$} \\
\hline day 104 & $164.3^{b}$ & $162.5^{b}$ & $192.8^{a}$ & $185.0^{a}$ & 2.81 & \multirow{2}{*}{$* * *$} & \multirow{2}{*}{$*$} & \multirow{2}{*}{$*$} \\
\hline day 149 & $173.3^{b}$ & $172.3^{b}$ & $201.5^{a}$ & $190.8^{a}$ & 2.81 & & & \\
\hline \multicolumn{9}{|c|}{ Rump width, cm } \\
\hline day 1 & $30.8^{b c}$ & $29.0^{c}$ & $41.8^{a}$ & $37.3^{\mathrm{ab}}$ & 1.38 & \multirow[t]{3}{*}{$* * *$} & \multirow[t]{3}{*}{ ns } & \multirow[t]{3}{*}{$\mathrm{ns}$} \\
\hline day 104 & 39.8 & 40.3 & 45.5 & 45.0 & 1.38 & & & \\
\hline day 149 & 41.5 & 42.5 & 47.8 & 44.3 & 1.38 & & & \\
\hline \multicolumn{9}{|c|}{ Rump length, cm } \\
\hline day 1 & $36.0^{b}$ & $36.5^{b}$ & $44.5^{a}$ & $42.8^{a b}$ & 1.36 & \multirow[t]{3}{*}{$* * *$} & \multirow[t]{3}{*}{ ns } & \multirow[t]{3}{*}{$*$} \\
\hline day 104 & 42.3 & 45.3 & 48.8 & 46.5 & 1.36 & & & \\
\hline day 149 & $43.3^{b}$ & $47.8^{\mathrm{ab}}$ & $51.3^{\mathrm{a}}$ & $50.0^{a b}$ & 1.36 & & & \\
\hline \multicolumn{9}{|c|}{ Body length, cm } \\
\hline day 149 & $140.8^{\mathrm{ab}}$ & $135.8^{b}$ & $154.8^{\mathrm{a}}$ & $146.5^{\mathrm{ab}}$ & 3.36 & $* * *$ & ns & ns \\
\hline
\end{tabular}

Abbreviations: C, control group; LW, initial live weight; S.E., standard error; T, vaccine treatment; VA, vaccinated group $\mathrm{ns} ; p>.05$

a,b,c Means within a row with different superscripts differing significantly $(p<.05)$.

${ }^{*} p<.05$.

${ }^{* * *} p<.001$.

\section{2 | Temperament}

There was no significant effect of either initial LW category, vaccine treatment, or time $(p>.05)$ on the chute scores (1-quiet to 4-violent struggling), as values were similar at the beginning (1.5 \pm 0.82$)$ and end of the fattening period $(1.3 \pm 0.45)$. Similarly, no effect was observed on flight speed $(1.8 \pm 0.57 \mathrm{~m} / \mathrm{s})$.

\section{3 | Testicular traits}

Concerning the ultrasound measurements, no intra-animal differences were identified between the left and the right testis ( $p>.05)$, so the mean value of both was calculated for each animal. Testicular diameter was affected by an interaction between the initial LW category and time $(p<.05)$ and between vaccine treatment and time $(p<.001)$. Testicular diameter from $C$ bulls increased throughout the study, especially in the LIGHT-C group, whereas VA bulls exhibited diminished testicular diameter (Figure 2). Mediastinum thickness was influenced by the initial LW category $(3.8 \pm 0.24$ vs. $4.9 \pm 0.24 \mathrm{~mm}$ for LIGHT and HEAVY, respectively, $p<.01)$ and vaccine treatment $(5.0 \pm 0.24$ vs. $3.7 \pm 0.24 \mathrm{~mm}$ for $C$ and VA, respectively, $p<.01)$, with no effect of time or any interaction.

Scrotal circumference results are detailed in Monleón, Noya, Garza, Ripoll, \& Sanz (in press), where it is reported that, in line with testicular diameter results, scrotal circumference in VA groups remained constant over time or even decreased, in contrast with $C$ groups, whose scrotal circumference increased, and did so faster in LIGHT-C than HEAVY-C bulls. Testicular diameter was highly correlated with scrotal circumference $(r=0.94, p<.001)$.

Regarding pixel intensity of the testis parenchyma, no differences were observed in reference to initial LW category $(52.4 \% \pm 1.80$ vs. $50.1 \% \pm 1.83$ for LIGHT and HEAVY, respectively, $p>.05)$, vaccine treatment $(49.8 \% \pm 1.83$ vs. $52.8 \% \pm 1.80$ for $\mathrm{C}$ and VA, respectively, $p>.05)$, or between left and right 


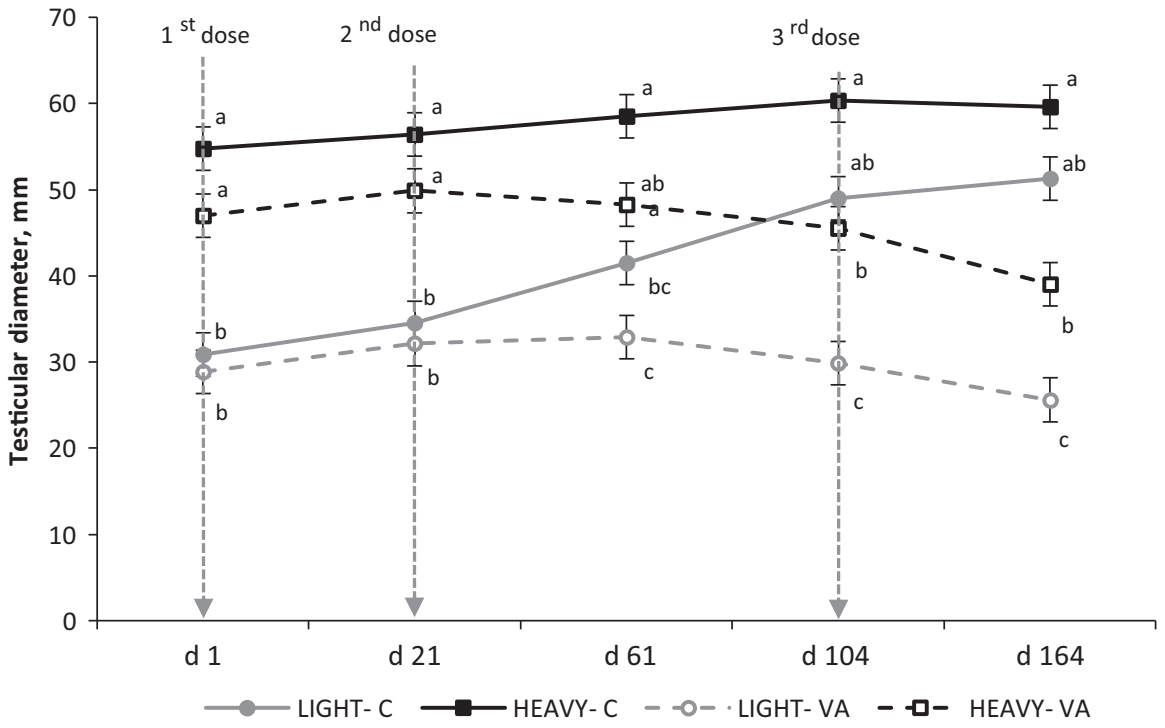

FIGURE 2 Testicular diameter in bulls during the experimental period according to the initial LW and vaccine treatment testicles within individual animals. However, VA animals exhibited increased variability in the echogenicity of posterior testicular parenchyma compared to $C$ animals (CVs: $9.0 \%$ vs. $15.2 \%$ for $C$ and VA groups, respectively).

\subsection{Subcutaneous fat and skin thickness}

Subcutaneous fat and skin thickness, measured at the 13th thoracic vertebra and $\mathrm{P} 8$ point, were influenced by the initial LW category $(p<.01)$, with higher values in HEAVY than LIGHT bulls, and time $(p<.001)$ (values increased throughout the study) but not by vaccine treatment $(p>.05)$. Subcutaneous fat and skin thickness values, measured throughout the study at the 13th thoracic vertebra, are shown in Figure 3. Values obtained for subcutaneous fat and skin thickness on the P8 point demonstrated similar evolution throughout time compared to the 13th thoracic vertebra (subcutaneous fat thickness on P8 point: from $2.0 \pm 0.50 \mathrm{~mm}$ on day 1 to $4.5 \pm 0.50 \mathrm{~mm}$ on day 164 for LIGHT groups, from $3.1 \pm 0.50 \mathrm{~mm}$ on day 1 to $7.5 \pm 0.50 \mathrm{~mm}$ on day 164 for HEAVY groups; skin thickness on P8 point: from $3.4 \pm 0.24 \mathrm{~mm}$ on day 1 to $5.2 \pm 0.24 \mathrm{~mm}$ on day 164 for LIGHT groups, from $4.9 \pm 0.24 \mathrm{~mm}$ on day 1 to $5.7 \pm 0.24 \mathrm{~mm}$ on day 164 for HEAVY groups).

\subsection{Hormones and metabolites}

Peripheral hormone and metabolite concentrations measured during the experimental period are shown in Figure 4 and Figure 5.

Testosterone concentrations were affected by the initial LW category $(p<.05)$ and by an interaction between vaccine treatment and time $(p<.001)$. No differences were observed among bulls at the start of the experiment, but from the 3 rd dose of the vaccine, testosterone concentration decreased in VA bulls with statistical differences between $C$ and VA bulls on day 132 and $164(p<.001)$. Due to the differences in the rapidity of the vaccine effect, a high variability among testosterone concentrations of VA animals was observed between the 2nd dose and the 3rd dose of the vaccine. Nevertheless, at the end of the experiment, testosterone concentration of VA animals decreased to residual values. No significant differences were found between LIGHT-C and HEAVY-C testosterone concentrations throughout the study $(p>.05)$. Testosterone concentration was positively correlated with testicular diameter but only in C bulls $(r=0.41, p<.05)$.

Plasma IGF-1 levels were influenced by the initial LW category, vaccine treatment, and time $(p<.05)$. At the start of the experiment, IGF-1 from HEAVY groups was higher compared to LIGHT groups, but at the end of the assay, the LIGHT-C group registered the highest values. LIGHT-VA animals had the lowest average plasma IGF-1 concentrations throughout the study, whereas no differences were observed among the other groups $(357.7 \pm 15.32,264.2 \pm 15.55$, $369.7 \pm 15.35$ and $350.6 \pm 15.51 \mathrm{ng} / \mathrm{ml}$ for LIGHT-C, LIGHT-VA, HEAVY-C and HEAVY-VA, respectively). Insulin-like growth factor-1 was positively correlated with testicular diameter $(r=0.59, p<.001)$.

Urea concentration was affected by initial LW category $(p<.01)$ and an interaction between vaccine and time $(p<.05)$. Mean values throughout the study were lower in LIGHT than in HEAVY animals $(4.2 \pm 0.18$ vs. $5.1 \pm 0.18 \mathrm{mmol} / \mathrm{L}$, respectively, $p<.01)$. Initial concentrations were similar between groups and increased over time. At the end of the experiment, urea concentration remained nearly constant in $\mathrm{C}$ groups, whereas they continued to increase in VA groups, with clear differences between LIGHT-C and HEAVY-VA animals on day 164 ( $4.1 \pm 0.28$ vs. $6.5 \pm 0.28 \mathrm{mmol} / \mathrm{L}$, respectively, $p<.01)$.

Neither the initial LW category nor vaccine treatment affected NEFA concentrations $(p>.05)$, which were higher in all groups at the start of the study and gradually declined over time $(p<.001)$. Average values ranged from $0.41 \pm 0.028 \mathrm{mmol} / \mathrm{L}$ on day 1 to $0.25 \pm 0.025 \mathrm{mmol} / \mathrm{L}$ on day 164 .

Plasma creatinine concentrations were affected by the interaction between the initial LW category and time $(p<.01)$ and between the initial LW category and vaccine treatment $(p<.05)$. Initially, values were lower in LIGHT than in HEAVY animals, increasing thereafter, and no differences were observed at the end of the experiment. 
FIGURE 3 Subcutaneous fat and skin thickness on 13th thoracic vertebra in bulls during the experimental period according to the initial $\mathrm{LW}$ and vaccine treatment
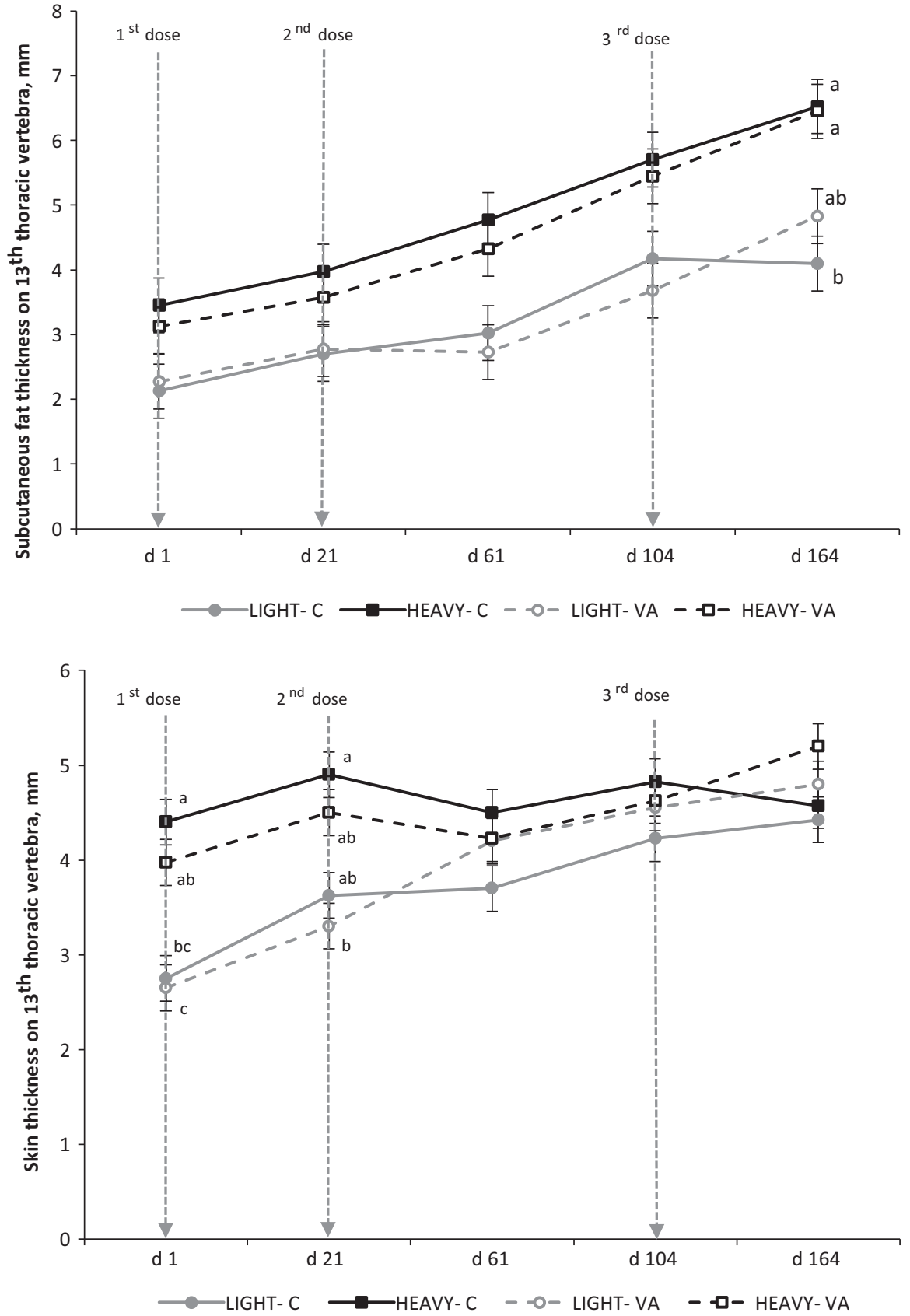

Creatinine concentrations were positively correlated with testicular diameter $(r=0.46, p<.001)$.

\section{4 | DISCUSSION}

\subsection{Animal performance}

It is well established that castration of male cattle impairs their performance, as castrated bulls tend to exhibit approximately $15 \%$ reduced levels of weight gain (Field, 1971) with higher feed conversion ratios (McNamee et al., 2015) than intact bulls. Ribeiro et al. (2004) demonstrated that intact bulls exhibited higher gains than either surgically or immunocastrated animals, which did not differ from each other. Amatayakul-Chantler et al. (2013) described lower ADG and dressing percentage in surgically castrated compared to immunocastrated bulls, but Moreira et al. (2018) found the opposite in terms of growth and food efficiency. Some authors describe similar gains between intact and immunocastrated males (D'Occhio, Aspden, \& Trigg, 2001; Janett et al., 2012). In contrast, Amatayakul-Chantler et al. (2012) reported that Bos indicus Zebu $\times$ Brown Swiss bulls immunized against $\mathrm{GnRH}$ at 13-14 months of age grew faster than non-vaccinated animals. These confounding results may be related to the age at which immunocastration or surgical castration is performed since older animals may experience more significant weight loss and stress responses after castration (Bretschneider, 2005). Manufacturer instructions recommend vaccinating during the post-pubertal stage to avoid a detrimental effect on growth rates. In contrast, 


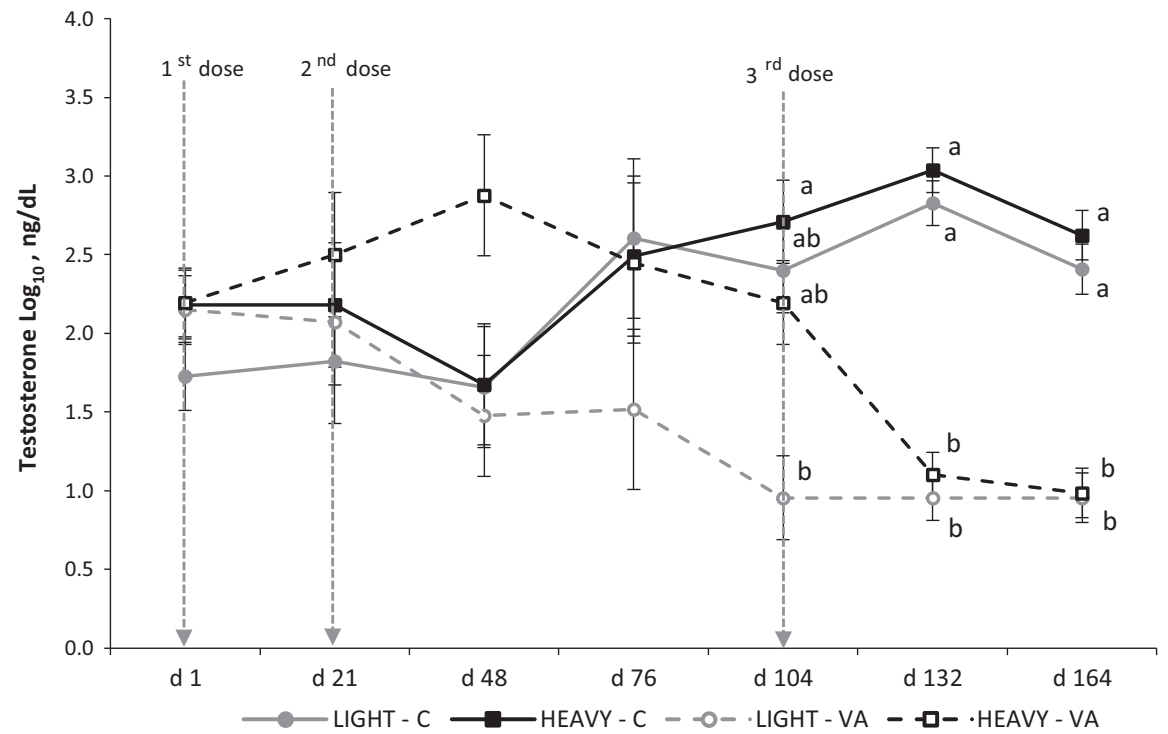

FIGURE 4 Plasma concentration of hormones (testosterone and IGF-1) in bulls during the experimental period according to the initial LW and vaccine treatment

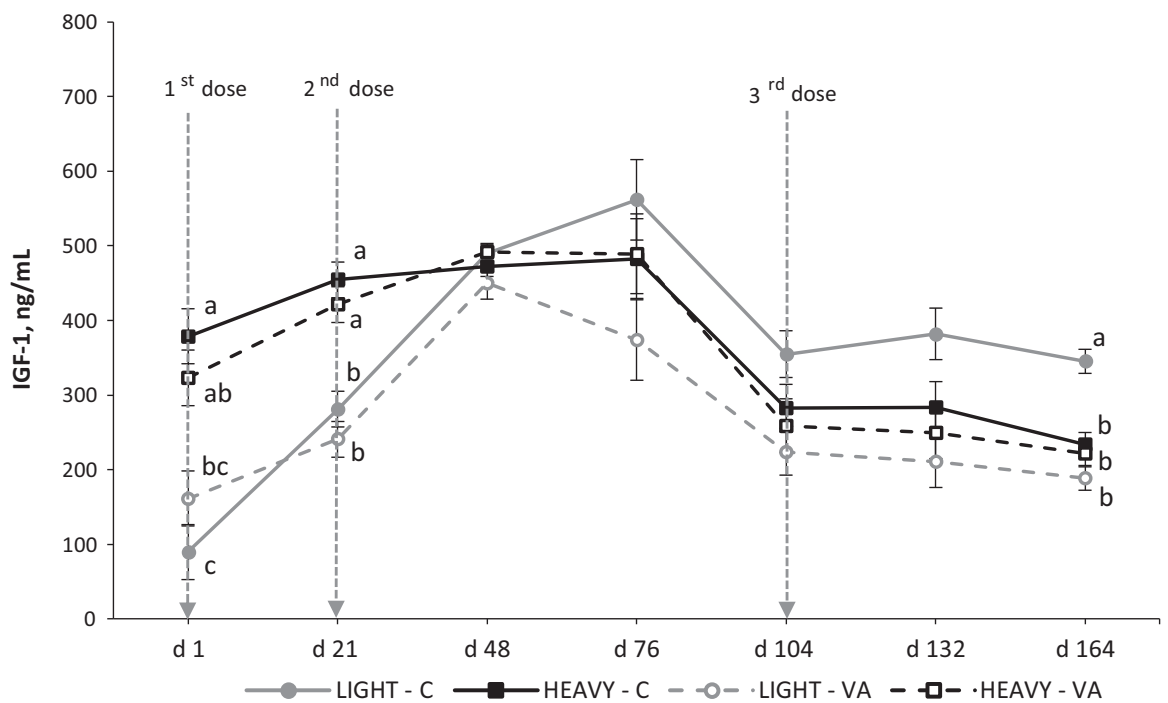

Adams, Daley, Adams, and Sakurai (1996) recommended vaccinating approximately at 7-month old because when performed earlier, the immunological system is still immature, and after that age, physiological effects of the vaccine decrease. In our study, bulls were $7.9 \pm 1.2$ (LIGHT) and $10.8 \pm 2.11$ (HEAVY) months old at the time of vaccination, and while almost all animals would be in a pre-pubertal stage according to their age and SC (Rawlings, Evans, Chandolia, \& Bagu, 2008), they were immunologically responsive and were therefore affected by vaccine treatment. We found no effect of the initial LW on the gains, implying that the vaccine was effective independent of the age at immunocastration.

Despite observed differences in weight gain, vaccine treatment exerted only minor effects on linear body measures, which are related to skeletal growth. Similarly, McNamee et al. (2015) described little difference among bulls and steers, while Biagini and Lazzaroni (2007) reported that castration only affected skeletal measures at 18 months when castration had been performed at 5 months of age but not post-pubertally.

\section{2 | Temperament}

Immunocastration reportedly reduces aggressiveness, male-male sexual behavior, and, in general, physical activity (Martí et al., 2015; Price, Adams, Huxsoll, \& Borgwardt, 2003). In the current study, neither the initial LW nor immunocastration had any effect on the chute score or flight speed tests, likely because of individual variability within this breed due to a lack of genetic selection (ÁlvarezRodríguez et al., 2017). In contrast to our results, Fina et al. (2006) described that temperament recorded during finishing depended upon initial weight in a feral breed, suggesting that older calves were less adaptable to intensive fattening systems. Concerning sexual phenotype, Grandin (1993) found that steers were calmer in a chute than bulls, but other authors reported higher chute scores (Vanderwert et al., 1985) and flight speed in steers than in bulls (Core, Widowski, Mason, \& Miller, 2009), perhaps because of the trauma and pain caused by castration. 
FIGURE 5 Plasma concentration of metabolites (urea, NEFA and creatinine) in bulls during the experimental period according to the initial $\mathrm{LW}$ and vaccine treatment
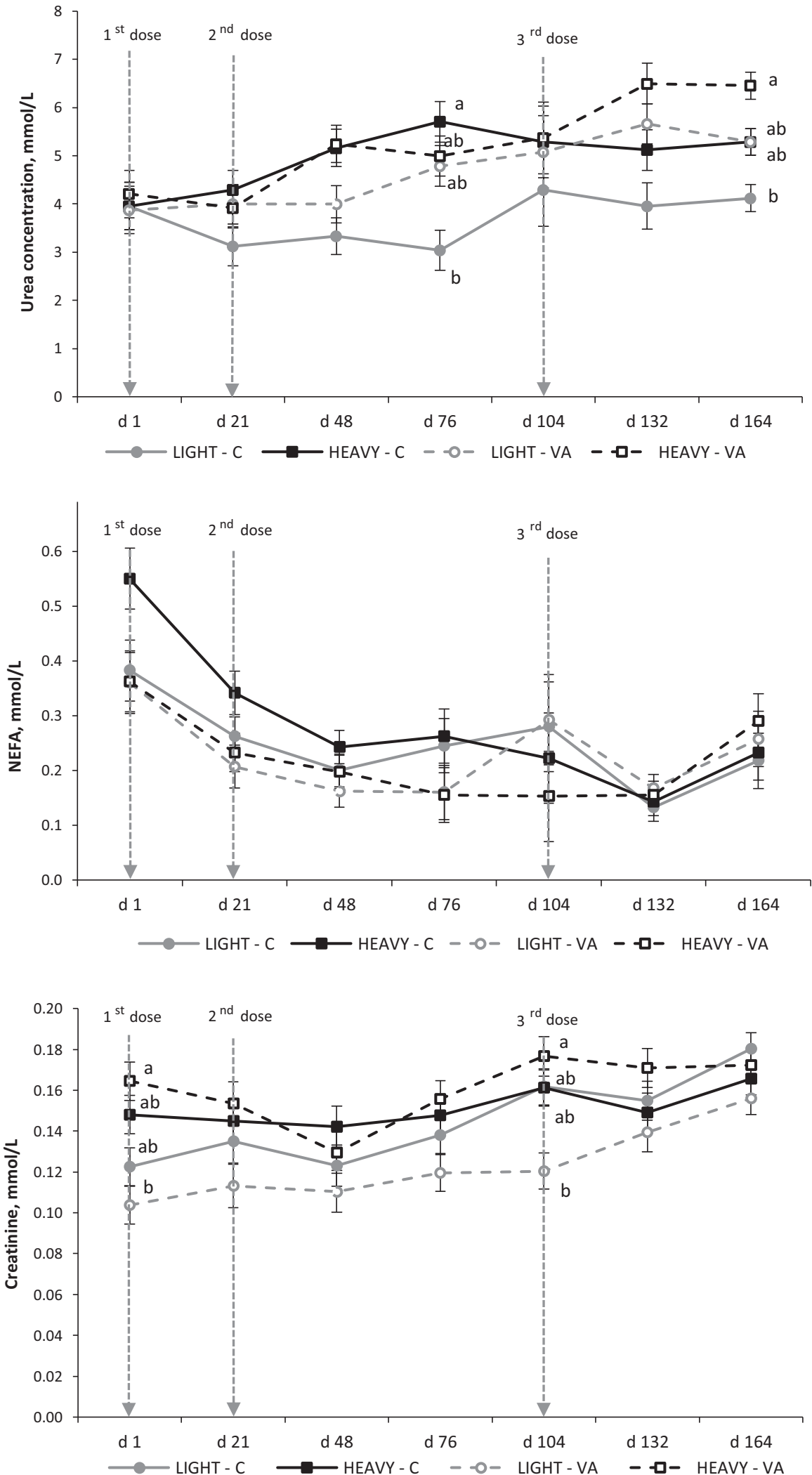

Petherick, Doogan, Holroyd, Olsson, and Venus (2009) reported that well-managed calves reduced their flight speed from 2.6 to $1.6 \mathrm{~m} / \mathrm{s}$ in fewer than 200 days, which was close to the values observed in our study for any time. Burrow and Dillon (1997) established 1.9 and $2.4 \mathrm{~m} / \mathrm{s}$ as the thresholds to define a calm and nervous animal, respectively, while these values were lower for Fell, Colditz, Walker, and Watson (1999) (1.4 and $1.9 \mathrm{~m} / \mathrm{s}$, respectively). According to these studies, animals from the current assay would be considered to have calm or intermediate temperaments. 


\section{3 | Testicular traits}

In the current study, testicular diameter reflected the testicle growth throughout the fattening period. Ultrasound measures of the testes in $\mathrm{C}$ animals increased with LW, as observed in other studies (Abdel-Razek \& Ali, 2005; Chandolia et al., 1997; Janett et al., 2012), confirming that immunocastration affects testicular structures by inhibiting their growth (Adams \& Adams, 1992; D'Occhio et al., 2001). Testicular diameter was highly correlated with scrotal circumference, an essential measure used in the soundness evaluation in bull breeding (Perumal, 2014). In line with our results, some investigators found a lack of scrotal circumference increase in immunocastrated bulls (Adams et al., 1996; D'Occhio et al., 2001; Janett et al., 2012).

Some authors described that immunocastration modifies testicular echogenicity, which normally increases in beef bulls during sexual development (Brito, Barth, Wilde, \& Kastelic, 2012) due to its positive correlation with size of the seminiferous tubules (Pozor et al., 2017). Ülker et al. (2005) reported lower parenchymal echogenicity in immunized ram lambs related to smaller seminiferous tubule diameter and thinner basal membranes than in control ram lambs. These authors found increased individual variability for this trait in immunocastrated rams, consistent with our results. However, in our study conditions, neither the initial LW nor immunocastration affected the pixel intensity of the testicles, although a later histological and immunohistochemical study of the testicular parenchyma revealed a decrease in the diameter of the seminiferous tubules and an abnormal cell population in VA animals (Monleón et al., in press). In this sense, some authors have suggested that testicular echogenicity is not a viable method for the indirect analysis of cellular population in the seminiferous epithelium, intrinsic spermatogenic performance, or the Sertoli cell index or semen quality (Dias et al., 2017).

\section{4 | Subcutaneous fat and skin thickness}

Ultrasound examination of fat thickness is an accurate estimator of carcass fat and body composition in live animals (Álvarez-Rodríguez, Blanco, Ripoll, Sanz, \& Casasús, 2009). Castrated animals exhibit increased fat deposition, harboring greater amounts of kidney, pelvic, and intramuscular fat (Purchas \& Grant, 1995). Testosterone has an inhibitory effect on lipogenic enzyme activity in the adipose tissue, inducing higher basal lipolytic rates (Prior, Smith, Schanbacher, \& Mersmann, 1983). Moreira et al. (2018) demonstrated that surgically castrated beef cattle exhibited greater back fat deposition at day 126 of the fattening period than immunocastrated and control calves. Immunocastrated animals needed 126 extra days to obtain greater back fat than control calves but had still not reached the levels of surgically castrated animals at slaughter. In the same line, Andreo et al. (2013) found higher subcutaneous fat thickness in immunocastrated calves than in intact calves. In the current experiment, subcutaneous fat thickness increased with animal LW and time on feed but was not affected by immunocastration. These results agree with those of other investigators (Cook, Popp, Kastelic,
Robbins, \& Harland, 2000; Miguel et al., 2014) and suggest that immunocastrated bulls need more fattening days to reach greater values of subcutaneous fat thickness than intact bulls. However, in the current study, despite immunocastration not increasing subcutaneous fat thickness, it did influence meat quality in these animals, improving tenderness and reducing the ageing time of their meat (Ripoll, Noya, Casasús, \& Sanz, 2019). On the other hand, according to our results, the skin thickness of the adult animals seems to be constant and it is not influenced by the breed (Ripoll et al., 2016) unlike young animals that increased their skin thickness because of their high growth rates.

\subsection{Hormones and metabolites}

Immunocastration affects testosterone concentration because newly created antibodies neutralize endogenous $\mathrm{GnRH}$, preventing $\mathrm{LH}$ production and consequently Leydig cell stimulation, which is responsible for testosterone production (Ramaswamy \& Weinbauer, 2014). In our study, VA calves received the second dose (booster) 3 weeks later than the first, followed by a further third dose on day 104. Testosterone decreased from the third dose onward to nearly undetectable levels in VA animals, demonstrating the effectiveness of the vaccine and protocol. From a practical point of view, these results confirm the convenience of using this vaccine in commercial farms, where animals of different ages are usually mixed. Other investigators administered the second dose at 4 weeks (Janett et al., 2012), 7 weeks (Amatayakul-Chantler et al., 2012), or 13 weeks later (Amatayakul-Chantler et al., 2013) than the first, observing decreased testosterone equivalent to that of surgically castrated animals. However, D'Occhio et al. (2001) administered the booster 16 weeks after the priming dose, and half of their immunocastrated animals had similar testosterone levels to control bulls. Moreover, Amatayakul-Chantler et al. (2013) demonstrated a temporary effect of the vaccine because 188 days after the booster, testosterone had returned to physiological values in $45 \%$ of immunocastrated bulls.

Insulin-like growth factor 1 mediates the anabolic effect of the growth hormone (Laron, 2001) through enhanced nutrient utilization (Lancaster et al., 2008). In our study, plasma IGF-1 concentrations were higher in LIGHT-C than LIGHT-VA animals, reflecting their distinct weight gains, although no differences were found between HEAVY-C and HEAVY-VA animals. Röpke, Schams, Schwarz, and Kirchgessner (1994) and Álvarez-Rodríguez et al. (2017) described lower plasma IGF-1 concentrations during the fattening period in surgically castrated animals than in intact bulls, suggesting IGF-1 may be increased by gonadal hormones, although Bruckmaier, Lehmann, Hugi, Hammon, and Blum (1998) reported that this difference disappeared approximately $450 \mathrm{~kg} \mathrm{LW}$. In contrast, IGF-1 is also related to reproductive function in males. In the current study, testicular diameter was positively correlated with IGF-1 plasma concentrations. Similarly, Yilmaz, Davis, and Simmen (1999) confirmed that scrotal circumference and the percentage of normal sperm cells were correlated with circulating IGF-1 levels in yearling Angus bulls; 
however, they did not identify differences in scrotal circumference between high- and low-IGF-1 selected lines of bulls.

Urea concentration is a good indicator of anabolic metabolism. Circulating amino acids obtained from feed protein breakdown are deposited in body tissues for growth, but when they exceed requirements, they will be catabolized, generating higher ammoniac and later urea plasma concentrations (Bach, 2002). In this study, C and LIGHT animals, which grew faster than VA and HEAVY groups, respectively, also exhibited reduced urea plasma concentrations from the 3 rd dose of the vaccine. This implies that ingested protein was assimilated to improve performance in $\mathrm{C}$ and LIGHT groups, whereas in their counterparts, part of it was catabolized.

Non-esterified fatty acids are a source of physiological fuel when blood glucose decreases. To satisfy energy demands, triglycerides from adipose tissue are hydrolyzed into NEFA, which reversibly bind to albumin and travel through the bloodstream to be $\beta$-oxidated in the mitochondrial matrix of cells. In fact, elevated NEFA concentrations are indicators of a negative energy balance (Adewuyi, Gruys, \& Van Eerdenburg, 2005). Herein, NEFA decreased throughout the study in all groups, indicating that dietary energy was adequate to satisfy maintenance and growth requirements. Differential gains due to immunocastration or the initial LW were not mirrored by the NEFA levels. These results agree with those of Ellenberger et al. (1989), who reported similar NEFA concentrations in beef cattle being managed to achieve different, but positive, rates of ADG.

Plasma creatinine is the product of muscle creatine catabolism (Silva et al., 2012) and is related to muscle mass and LW. Gregory, Birgel Junior, D'Angelino, Benesi, and Birgel (2004) reported reduced values of serum creatinine in animals $<12$ months compared to 12- to 24-month-old cattle, irrespective of gender. Accordingly, the differences found in this study were only related to the initial LW but not to vaccine treatment.

\section{5 | CONCLUSIONS}

In conclusion, vaccinated calves exhibited lower weight gain, testicular growth, and plasmatic testosterone than intact bulls, regardless of weight at the start of immunization. With the studied vaccine schedule and fattening period, immunocastration did not affect back fat deposition or temperament. Our results confirm anti-GnRH vaccination as an efficient and painless method to stop the reproductive development of fattening bulls. These results are particularly relevant to facilitating management in breeds that may be more reactive to other castration methods.

\section{ACKNOWLEDGMENTS}

The authors would like to thank the farm staff at CITA de Aragón for their technical support and ASERNA for their collaboration. This work was supported by Spanish Ministry of Science, Innovation and Universities and the European Regional Development Funds under
Grant INIA RTA 2013-00059-C02 and Teruel Investment Funds (FITE 451A and FITE 551A); and the Government of Aragón under the Grant Research Group Funds (A14_17R). A. Noya received a grant from INIA Government of Spain.

\section{CONFLICT OF INTEREST}

None.

\section{ORCID}

Agustí Noya (iD https://orcid.org/0000-0002-9552-4709

Guillermo Ripoll (iD https://orcid.org/0000-0001-8042-8688

Isabel Casasús (iD https://orcid.org/0000-0003-3943-5311

Albina Sanz iD https://orcid.org/0000-0002-8122-0069

\section{REFERENCES}

Abdel-Razek, A., \& Ali, A. (2005). Developmental changes of bull (Bos taurus) genitalia as evaluated by caliper and ultrasonography. Reproduction in Domestic Animals, 40(1), 23-27. https://doi org/10.1111/j.1439-0531.2004.00549.x

Adams, T. E., \& Adams, B. M. (1992). Feedlot performance of steers and bulls actively immunized against gonadotropin-releasing hormone. Journal of Animal Science, 70(6), 1691-1698. https://doi. org/10.2527/1992.7061691x

Adams, T. E., Daley, C. A., Adams, B. M., \& Sakurai, H. (1996). Testes function and feedlot performance of bulls actively immunized against gonadotropin-releasing hormone: Effect of age at immunization. Journal of Animal Science, 74(5), 950-954. https://doi. org/10.2527/1996.745950x

Adewuyi, A., Gruys, E., \& Van Eerdenburg, F. (2005). Non esterified fatty acids (NEFA) in dairy cattle. A Review. Veterinary Quarterly, 27(3), 117126. https://doi.org/10.1080/01652176.2005.9695192

Álvarez-Rodríguez, J., Albertí, P., Ripoll, G., Blasco, I., \& Sanz, A. (2017). Effect of castration at 10 months of age on growth physiology and behavior of male feral beef cattle. Animal Science Journal, 88(7), 991998. https://doi.org/10.1111/asj.12728

Álvarez-Rodríguez, J., Blanco, M., Ripoll, G., Sanz, A., \& Casasús, I. (2009). Body composition in mature Parda de Montaña and Pirenaica suckler cows. Spanish Journal of Agricultural Research, 7(1), 147-154. https:// doi.org/10.5424/sjar/2009071-399

Amatayakul-Chantler, S., Hoe, F., Jackson, J. A., Roca, R. O., Stegner, J. E., King, V., ... Walker, J. (2013). Effects on performance and carcass and meat quality attributes following immunocastration with the gonadotropin releasing factor vaccine Bopriva or surgical castration of Bos indicus bulls raised on pasture in Brazil. Meat Science, 95(1), 78-84. https://doi.org/10.1016/j.meatsci.2013.04.008

Amatayakul-Chantler, S., Jackson, J., Stegner, J., King, V., Rubio, L., Howard, R., ... Walker, J. (2012). Immunocastration of Bos indicus $x$ Brown Swiss bulls in feedlot with gonadotropin-releasing hormone vaccine Bopriva provides improved performance and meat quality. Journal of Animal Science, 90(11), 3718-3728. https://doi. org/10.2527/jas.2011-4826

Andreo, N., Bridi, A. M., Tarsitano, M. A., Peres, L. M., da Costa Barbon, A. P. A., de Andrade, E. L., \& Prohmann, P. E. F. (2013). Influence of immunocastration (Bopriva $($ ) in weight gain, carcass characteristics and meat quality of Nellore. Semina: Ciências Agrárias 34, 4121-4132. https://doi.org/10.5433/1679-0359.2013v34n6S upl 2 p 4121 
Bach, A. (2002). La reproducción del vacuno lechero: Nutrición y fisiología. Purina, Spain: Paper presented at the XVII Curso de Especialización FEDNA.

Biagini, D., \& Lazzaroni, C. (2007). Effect of pre-and post-pubertal castration on Piemontese male calves: I. Live and Slaughtering Performances. Livestock Science, 110(1-2), 181-186. http://doi. org/10.1016/j.livsci.2006.06.005

Bretschneider, G. (2005). Effects of age and method of castration on performance and stress response of beef male cattle: A review. Livestock Production Science, 97(2-3), 89-100. https://doi.org/10.1016/j.livpr odsci.2005.04.006

Brito, L. F. C., Barth, A. D., Wilde, R. E., \& Kastelic, J. P. (2012). Testicular ultrasonogram pixel intensity during sexual development and its relationship with semen quality, sperm production, and quantitative testicular histology in beef bulls. Theriogenology, 78(1), 69-76. https ://doi.org/10.1016/j.theriogenology.2012.01.022

Bruckmaier, R., Lehmann, E., Hugi, D., Hammon, H., \& Blum, J. (1998). Ultrasonic measurement of longissimus dorsi muscle and backfat, associated with metabolic and endocrine traits, during fattening of intact and castrated male cattle. Livestock Production Science, 53(2), 123-134. https://doi.org/10.1016/S0301-6226(97)00162-0

Brunius, C., Zamaratskaia, G., Andersson, K., Chen, G., Norrby, M., Madej, A., \& Lundström, K. (2011). Early immunocastration of male pigs with Improvac $\AA$-Effect on boar taint, hormones and reproductive organs. Vaccine, 29(51), 9514-9520. https://doi.org/10.1016/j. vaccine.2011.10.014

Burrow, H., \& Dillon, R. (1997). Relationships between temperament and growth in a feedlot and commercial carcass traits of Bos indicus crossbreds. Australian Journal of Experimental Agriculture, 37(4), 407-411. https://doi.org/10.1071/EA96148

Burrow, H., Seifert, G., \& Corbet, N. (1988). A new technique for measuring temperament in cattle. Paper presented at the Australian Society of Animal Production Conference.

Chandolia, R., Honaramooz, A., Omeke, B., Pierson, R., Beard, A., \& Rawlings, N. (1997). Assessment of development of the testes and accessory glands by ultrasonography in bull calves and associated endocrine changes. Theriogenology, 48(1), 119-132. https://doi. org/10.1016/S0093-691X(97)00195-7

Coetzee, J. F. (2011). A review of pain assessment techniques and pharmacological approaches to pain relief after bovine castration: Practical implications for cattle production within the United States. Applied Animal Behaviour Science, 135(3), 192-213. https://doi. org/10.1016/j.applanim.2011.10.016

Cook, R., Popp, J., Kastelic, J., Robbins, S., \& Harland, R. (2000). The effects of active immunization against $\mathrm{GnRH}$ on testicular development, feedlot performance, and carcass characteristics of beef bulls. Journal of Animal Science, 78(11), 2778-2783. https://doi. org/10.2527/2000.78112778x

Core, S., Widowski, T., Mason, G., \& Miller, S. (2009). Eye white percentage as a predictor of temperament in beef cattle. Journal of Animal Science, 87(6), 2168-2174. https://doi.org/10.2527/jas.2008-1554

Creutzinger, K. C., Stookey, J. M., Marfleet, T. W., Campbell, J. R., Janz, D. M., Marqués, F. J., \& Seddon, Y. M. (2017). An investigation of hair cortisol as a measure of long-term stress in beef cattle: Results from a castration study. Canadian Journal of Animal Science, 97(3), 499-509. https://doi.org/10.1139/cjas-2016-0206

D'Occhio, M. J., Aspden, W. J., \& Trigg, T. E. (2001). Sustained testicular atrophy in bulls actively immunized against $\mathrm{GnRH}$ : Potential to control carcase characteristics. Animal Reproduction Science, 66(1), 47-58. https://doi.org/10.1016/S0378-4320(01)00091-4

Dias, W., Faria, F. J., Fernandes, C. A., Sampaio, B. F., Santos, M. D., Rodrigues, W. B., ... Costa, D. S. (2017). Testicular echotexture is not a viable method to indirectly evaluate the spermatogenic parameters in Nelore bulls. Austral Journal of Veterinary Sciences, 49(1), 45-51. https://doi.org/10.4067/S0719-81322017000100045
Ellenberger, M. A., Johnson, D., Carstens, G., Hossner, K., Holland, M., Nett, T., \& Nockels, C. (1989). Endocrine and metabolic changes during altered growth rates in beef cattle. Journal of Animal Science, 67(6), 1446-1454. https://doi.org/10.2527/jas1989.6761446x

Fell, L., Colditz, I., Walker, K., \& Watson, D. (1999). Associations between temperament, performance and immune function in cattle entering a commercial feedlot. Australian Journal of Experimental Agriculture, 39(7), 795-802. https://doi.org/10.1071/EA99027

Field, R. (1971). Effect of castration on meat quality and quantity. Journal of Animal Science, 32(5), 849-858. https://doi.org/10.2527/jas19 $71.325849 x$

Fina, M., Casellas, J., Manteca, X., \& Piedrafita, J. (2006). Analysis of temperament development during the fattening period in the semi-feral bovine calves of the Alberes Massif. Animal Research, 55(5), 389-395. http://doi.org/10.1051/animres:2006030

Grandin, T. (1993). Behavioral agitation during handling of cattle is persistent over time. Applied Animal Behaviour Science, 36(1), 1-9. https://doi.org/10.1016/0168-1591(93)90094-6

Gregory, L., Birgel Junior, E., D'Angelino, J., Benesi, F., \& Birgel, E. (2004). Valores de referência dos teores séricos da uréia e creatinina em bovinos da raça Jersey criados no Estado de São Paulo. Influência dos fatores etários, sexuais e da infecção pelo vírus da leucose dos bovinos. Arquivo do Instituto De Biologia, 71(3), 339-345.

Janett, F., Gerig, T., Tschuor, A., Amatayakul-Chantler, S., Walker, J., Howard, R., ... Thun, R. (2012). Vaccination against gonadotropin-releasing factor (GnRF) with Bopriva significantly decreases testicular development, serum testosterone levels and physical activity in pubertal bulls. Theriogenology, 78(1), 182-188. https://doi. org/10.1016/j.theriogenology.2012.01.035

Lancaster, P. A., Carstens, G. E., Ribeiro, F. R. B., Davis, M. E., Lyons, J. G., \& Welsh, T. H. (2008). Effects of divergent selection for serum insulin-like growth factor-I concentration on performance, feed efficiency, and ultrasound measures of carcass composition traits in Angus bulls and heifers. Journal of Animal Science, 86(11), 2862-2871. https://doi.org/10.2527/jas.2008-1083

Laron, Z. (2001). Insulin-like growth factor 1 (IGF-1): A growth hormone. Molecular Pathology, 54(5), 311-316. https://doi.org/10.1136/ mp.54.5.311

Martí, S., Devant, M., Amatayakul-Chantler, S., Jackson, J., Lopez, E., Janzen, E., \& Schwartzkopf-Genswein, K. (2015). Effect of anti-gonadotropin-releasing factor vaccine and band castration on indicators of welfare in beef cattle. Journal of Animal Science, 93(4), 15811591. http://doi.org/10.2527/jas.2014-8346

McNamee, A., Keane, M., Kenny, D., Moloney, A., Buckley, F., \& O'Riordan, E. (2015). Beef production from Holstein-Friesian, Norwegian Red $\times$ Holstein-Friesian and Jersey $\times$ Holstein-Friesian male cattle reared as bulls or steers. Livestock Science, 173, 95-105. https://doi.org/10.1016/j.livsci.2014.12.009

Miguel, G. Z., Faria, M. H., Roça, R. O., Santos, C. T., Suman, S. P., Faitarone, A. B., ... Barbosa, E. K. (2014). Immunocastration improves carcass traits and beef color attributes in Nellore and Nellore $\times$ Aberdeen Angus crossbred animals finished in feedlot. Meat Science, 96(2), 884-891. https://doi.org/10.1016/j.meatsci.2013.08.030

Monleón, E., Noya, A., Garza, M. C., Ripoll, G., \& Sanz, A. (In press). Effects of an anti-gonadotrophin releasing hormone vaccine on the morphology, structure and function of bull testes. Theriogenology. https://doi.org/10.1016/j.theriogenology.2019.07.019.

Moreira, A. D., Siqueira, G. R., Lage, J. F., Benatti, J. M. B., Moretti, M. H., Miguel, G. Z., ... de Resende, F. D. (2018). Castration methods in crossbred cattle raised on tropical pasture. Animal Production Science, 58(7), 1307-1315. https://doi.org/10.1071/AN16580

Pang, W. Y., Earley, B., Gath, V., \& Crowe, M. A. (2008). Effect of banding or burdizzo castration on plasma testosterone, acute-phase proteins, scrotal circumference, growth, and health of bulls. Livestock Science, 117(1), 79-87. https://doi.org/10.1016/j.livsci.2007.11.012 
Perumal, P. (2014). Scrotal circumference and its relationship with testicular growth, age, and body weight in Tho Tho (Bos indicus) bulls. International Scholarly Research Notices, 2014, 249537. https://doi. org/10.1155/2014/249537

Petherick, J. C., Doogan, V. J., Holroyd, R. G., Olsson, P., \& Venus, B. K. (2009). Quality of handling and holding yard environment, and beef cattle temperament: 1 . Relationships with flight speed and fear of humans. Applied Animal Behaviour Science, 120(1), 18-27. https://doi. org/10.1016/j.applanim.2009.05.008

Pinho, R. O., Costa, D. S., Siqueira, J. B., Chaya, A. Y., Neto, T. M., Martins, L. F., ... Guimarães, J. D. (2012). Testicular echotexture and seminal quality of young Montana Tropical Compound bulls classified as sound and unsound for breeding. Revista Brasileira De Zootecnia, 41(8), 1961-1965. https://doi.org/10.1590/S1516-3598201200 0800023

Pozor, M., Morrissey, H., Albanese, V., Khouzam, N., Deriberprey, A., Macpherson, M. L., \& Kelleman, A. A. (2017). Relationship between echotextural and histomorphometric characteristics of stallion testes. Theriogenology, 99, 134-145. https://doi.org/10.1016/j.theri ogenology.2017.05.031

Price, E. O., Adams, T. E., Huxsoll, C. C., \& Borgwardt, R. E. (2003). Aggressive behavior is reduced in bulls actively immunized against gonadotropin-releasing hormone. Journal of Animal Science, 81(2), 411-415. https://doi.org/10.2527/2003.812411x

Prior, R., Smith, S., Schanbacher, B., \& Mersmann, H. (1983). Lipid metabolism in finishing bulls and steers implanted with oestradiol-17 $\beta$ dipropionate. Animal Science, 37(1), 81-88. https://doi.org/10.1017/ S0003356100001562

Purchas, R., \& Grant, D. (1995). Liveweight gain and carcass characteristics of bulls and steers farmed on hill country. New Zealand Journal of Agricultural Research, 38(1), 131-142. https://doi.org/10.1080/00288 233.1995.9513112

Ramaswamy, S., \& Weinbauer, G. F. (2014). Endocrine control of spermatogenesis: Role of FSH and LH/testosterone. Spermatogenesis, 4(2), e996025. https://doi.org/10.1080/21565562.2014.996025

Rawlings, N., Evans, A., Chandolia, R., \& Bagu, E. (2008). Sexual maturation in the bull. Reproduction in Domestic Animals, 43(s2), 295-301. https://doi.org/10.1111/j.1439-0531.2008.01177.x

Ribeiro, E. L., Hernandez, J. A., Zanella, E. L., Shimokomaki, M., Prudencio-Ferreira, S. H., Youssef, E., ... Reeves, J. J. (2004). Growth and carcass characteristics of pasture fed LHRH immunocastrated, castrated and intact Bos indicus bulls. Meat Science, 68(2), 285-290. https://doi.org/10.1016/j.meatsci.2004.03.008

Ripoll, G., Albertí, P., Álvarez-Rodríguez, J., Blasco, I., \& Sanz, A. (2016). Body size, carcass and meat quality of three commercial beef categories of 'Serrana de Teruel' breed. Spanish Journal of Agricultural Research, 14(3), e0604. https://doi.org/10.5424/sjar/2016143-9122

Ripoll, G., Noya, A., Casasús, I., \& Sanz, A. (2019). Preliminary study of the effects of an anti-gonadotropin-releasing factor vaccine at two initial liveweights on the carcass traits and meat quality of bulls. Animal Production Science, 59(8), 1462-1469. https://doi.org/10.1071/AN18324

Robinson, D., McDonald, C., Hammond, K., \& Turner, J. (1992). Live animal measurement of carcass traits by ultrasound: Assessment and accuracy of sonographers. Journal of Animal Science, 70(6), 16671676. https://doi.org/10.2527/1992.7061667x

Röpke, R., Schams, D., Schwarz, F., \& Kirchgessner, M. (1994). Growth-related hormones in plasma of bulls, steers and heifers given food with two different energy levels. Animal Science, 59(3), 367-377. https:// doi.org/10.1017/S0003356100007893

Sanz, A., Albertí, P., Blasco, I., Ripoll, G., Bernués, A., Zaragoza, P., ... Álvarez-Rodríguez, J. (2013). Producción de carne bovina de calidad diferenciada en el marco de un programa de conservación de la raza Serrana de Teruel. Animal Genetic Resources/Resources Génétiques animales/Recursos Genéticos Animales, 53, 147-155. https://doi. org/10.1017/S2078633612000100

Silva, L. F. C., Valadares Filho, S. C., Chizzotti, M. L., Rotta, P. P., Prados, L. F., Valadares, R. F. D., ... Braga, J. M. S. (2012). Creatinine excretion and relationship with body weight of Nellore cattle. Revista Brasileira De Zootecnia, 41, 807-810. https://doi.org/10.1590/S1516-35982 012000300046

Stafford, K., \& Mellor, D. (2005). The welfare significance of the castration of cattle: A review. New Zealand Veterinary Journal, 53(5), 271278. https://doi.org/10.1080/00480169.2005.36560

Ülker, H., Kanter, M., Gökdal, Ö., Aygün, T., Karakuş, F., Sakarya, M. E., \& Reeves, J. J. (2005). Testicular development, ultrasonographic and histological appearance of the testis in ram lambs immunized against recombinant LHRH fusion proteins. Animal Reproduction Science, 86(3), 205-219. https://doi.org/10.1016/j. anireprosci.2004.07.011

Vanderwert, W., Berger, L. L., McKeith, F. K., Baker, A. M., Gonyou, H. W., \& Bechtel, P. J. (1985). Influence of zeranol implants on growth, behavior and carcass traits in Angus and Limousin bulls and steers. Journal of Animal Science, 61(2), 310-319. https://doi.org/10.2527/ jas1985.612310x

Vijil, E., Picot, A., Hernández, M., Pastor, F., Quintín, F., Sevilla, E., ... Sanz, A. (2009). Raza bovina Serrana de Teruel: Estructura poblacional, características reproductivas y maternales. Archivos De Zootecnia, 58(1), 517-520.

Wicks, N., Crouch, S., \& Pearl, C. A. (2013). Effects of Improvac and Bopriva on the testicular function of boars ten weeks after immunization. Animal Reproduction Science, 142(3), 149-159. https://doi. org/10.1016/j.anireprosci.2013.09.017

Yilmaz, A., Davis, M. E., \& Simmen, R. C. (1999). Reproductive performance of bulls divergently selected on the basis of blood serum insulin-like growth factor I concentration. Journal of Animal Science, 77(4), 835-839. https://doi.org/10.2527/1999.774835x

How to cite this article: Noya A, Ripoll G, Casasús I, Sanz A. Effects of immunocastration performed at two live weights on the growth physiology, temperament and testicular development of feral beef bulls. Anim Sci J. 2019;00:1-13. https://doi.org/10.1111/asj.13307 